\title{
Retracing Ancestral Footsteps
}

\section{Introduction}

In Aotearoa New Zealand, retracing the footsteps of famous Maori tipuna or ancestral trails is not a new phenomena, but the availability of social media has enabled this information more accessible, reaching a wider audience. Events span from retracing tribal battles, following ancestral mountain trails to the moana and beyond. One such voyage, involved a group of 50 students from Tauranga Moana, who retraced their ancestral connections of the Takitimu waka back to Rarotonga (Te Kanawa, 30 July 2016). The Commemoration of the Battle of Ruapekapeka also followed the footsteps of tipuna, the famous warrior chief Te Ruki Kawiti and his peoples, whose memories were honoured by a 400 strong haka party, dignitaries, politicians and hundreds of people, (Forbes, 2016). Following the journey of Tainui rangatira, was a pre-season bonding exercise that Waikato Chiefs rugby coach Dave Rennie identified as beneficial for his players to learn more about their surroundings '...an arduous two-day torture test which connected with the past, the land, the people and the sea they will represent this season' (Napier, 2013).

Over the last three decades, there has also been an increasing interest in the histories of Māori prophets throughout Aotearoa. The journey of children from Parihaka $\mathrm{Pa}$ was made into a documentary named Tatarakihi: The Children of Parihaka (2012), which followed the ancestral journey of their tipuna Te Whiti ō Rongomai and Tohu Kākahi (and their people), arrested in Parihaka Taranaki for ploughing their land and wrongfully imprisoned in Christchurch and Dunedin without

Kelli Te Maihāroa (Waitaha) an uri of the prophet Te Maihāroa, is a Learning Advisor Maori for the Western Institute of Technology Taranaki, focus on Maori education and indigenous pedagogies. Her research interests include the rights of First Nations Peoples and peace education. 
trial (www.parihakafilm.com; https://www.nzonscreen.com). The Tamakaimoana people also undertook a pilgrimage in December 2013 to retrace the footsteps of their prophet Rua Kenana from Maungapōhatu (Te Karere, April 4 2016). Several Gisborne iwi recently retraced the route from Gisborne to the Rēkohu Chatham Islands following their prophet Te Kooti Arikirangi (Smith, 2016). Retracing the footsteps of ancestors is not only a physical undertaking, but for many, also an emotional, cultural and spiritual journey. The Waitaha People of Te Waipounamu South Island, retraced Te Maihāroa (? 1885) and Te Heke (The Migration 1877-79) on a contemporary peace walk called Te Heke Omaramataka (2012). The experiences of these trekkers were captured by filmmaker Bronwyn Judge in a free to view documentary entitled Te Heke 2012 Waitaki Mouth to Omarama' (Judge, B, 2012, Youtube: Te Heke 2012 Waitaki Mouth to Omarama). This paper is based on the whanau journals recorded by participants as they trekked from the Waitaki river mouth to Omarama in December 2012 .

\section{Background information}

In 1877, Te Maihāroa led Te Heke from Te Umu Kaha (Temuka) to Te Ao Marama (Omarama), in the South Island of Aotearoa New Zealand, in order to distance his people from colonisation and to protect their tribal lifeways. The suggestion to remember this historical event by retracing ancestral footsteps, transpired from a whānau discussion to celebrate this occasion and to honour the mauri life-force of the ancestral Waitaki River. This paper explores participants encounters through whānau journals and the visual representation of family photos, in order to not only highlight these experiences, but also to leave a trail of footsteps and memories for future generations. Te Maihāroa was a direct descendant of the South Island's founding Waitaha ancestor, Rākaihautū, and strongly opposed Māori land sales to colonial settlers. He believed that Papatūānuku (Earth Mother) should not be sold or exchanged for what he considered "blood 
money" (Te Maihāroa, R., 2013) and that his people had not consented to the land sales. Te Maiharoa strongly advocated that the million and a half acres between Ashburton to Maungatua (Taieri) was never sold and therefore remained ancestral land (Otago Witness, 1886; Evening Star, 1886; Mikaere, 1988).

After fruitless deliberations with local and National bodies, including the British Crown, Te Maihāroa concluded that only physical occupation of the hinterland would provide the necessary isolation required to retain tino rakatirataka (absolute sovereignty) and to preserve tribal traditions (Beattie Collection, 1939-1945; Mikaere, 1988; Te Maihāroa, K., 2015; Devere, Te Maihāroa, Solomon \& Wharehoka, 2016). In June 1877, Te Maihāroa led 150 of his people on the migration journey of almost two hundred kilometres, from their home in Temuka to Omarama. This event, called Te Heke Ki Te Ao Marama (The Migration to Enlightenment) or the 'Promised Land', has been written about by several authors (Beattie Collection, 1939-1945; Taylor, 1952; Te Maiharoa, 1957; Mikaere, 1988; Elsmore, 1999; Te Maihāroa, 2015; Devere, Te Maihāroa, Solomon \& Wharehoka, 2016).

'To this day, Te Maihāroa remains in our hearts as our spiritual guide, prophet and peaceful leader. His prophecy was for our people to return to Omarama, his vision of the 'Promised Land', to fulfil 'Judaic Law of Return'. Through Te Heke 1877, the migration for peace, Te Maihāroa kept alive ahi kā roa (the eternal sacred fires) of Waitaha, and asserted moral ownership within the interior hinterland. To celebrate 135 years since the original 'Te Heke', the Te Maihāroa whānui (family and friends) retraced much of the original route from the mouth of the Waitaki Valley to Omarama in December 2012. The latest journey named 'Te Heke Omaramataka' 2012 followed the sacred footsteps of our ancestors to remember their strength, courage, and motivation for undertaking the peaceful migration' (Ruka, 2012). 


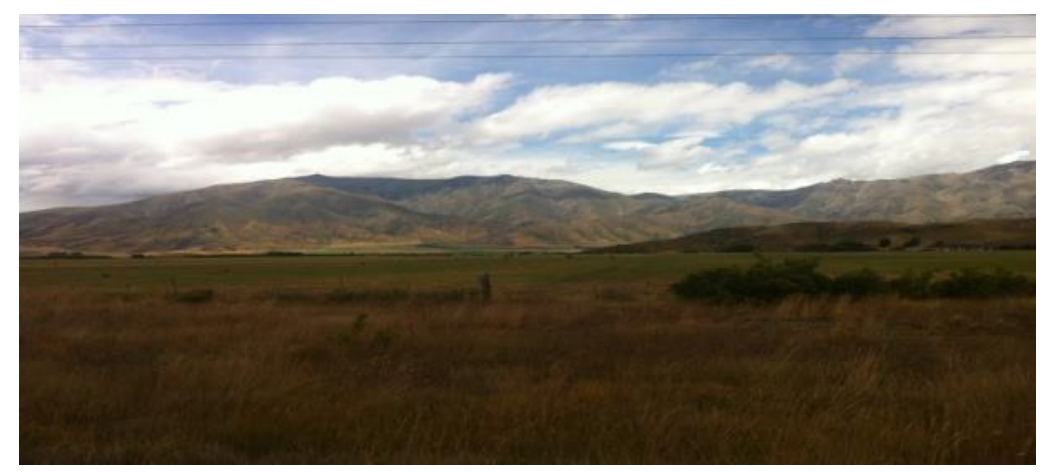

Figure 1: 'The Promised Land' at Omarama, where Te Maihāroa and his people established a Māori village 1877-1879. Personal whānau collection.

\section{Kaupapa Māori (Māori Themed) Research}

This paper traces the experiences of the participants on this commemorative walk through personal whānau journals. When the initial idea to retrace the footsteps of Te Maihāroa and Te Heke 1877 was first mooted in April 2012, there were two primary reasons driving this kaupapa: to commemorate Te Maihāroa and Te Heke (1877), and secondly, to draw attention to the diminishing mauri life force of the Waitaki River. Mauri is often referred to the life principal of a person (Williams, 2001), but in this context refers to the life essence of a river. This research adopted a kaupapa Māori or Māori potential approach towards gathering, writing and disseminating information in a way that honoured the experiences of the participants and promoted agency and self-determination. Kaupapa Māori is a vehicle for transformative change by positioning 'Māori potential' through the lens of Māori philosophies, principles and values (Bishop, 1996, 2005; Mead, 1994; Royal, 1998; Tuhiwai Smith, 1999; Smith, 2003). Embedded within this approach are notions of integrity and respect for research participants, shared decision making and working towards a shared collective vision (Bishop, 2005). In alignment with kaupapa 
Maori research, there was no attempt to provide any interpretative overlay or analysis, rather the participants narratives are arranged in a way that uses their own words to speak to the reader directly about their experience. Around the same time that the idea was floated to retrace Te Heke 1877, an archived photograph came to light in the Hocken Library, entitled 'Te Heke (The Migration) to Omarama', prompted interest within the whānau to find out more about the lives of our tîpuna. This photo also inspired the writer to consider potential ways of the authentically recording participants experiences on the contemporary event of Te Heke Omaramataka 2012.

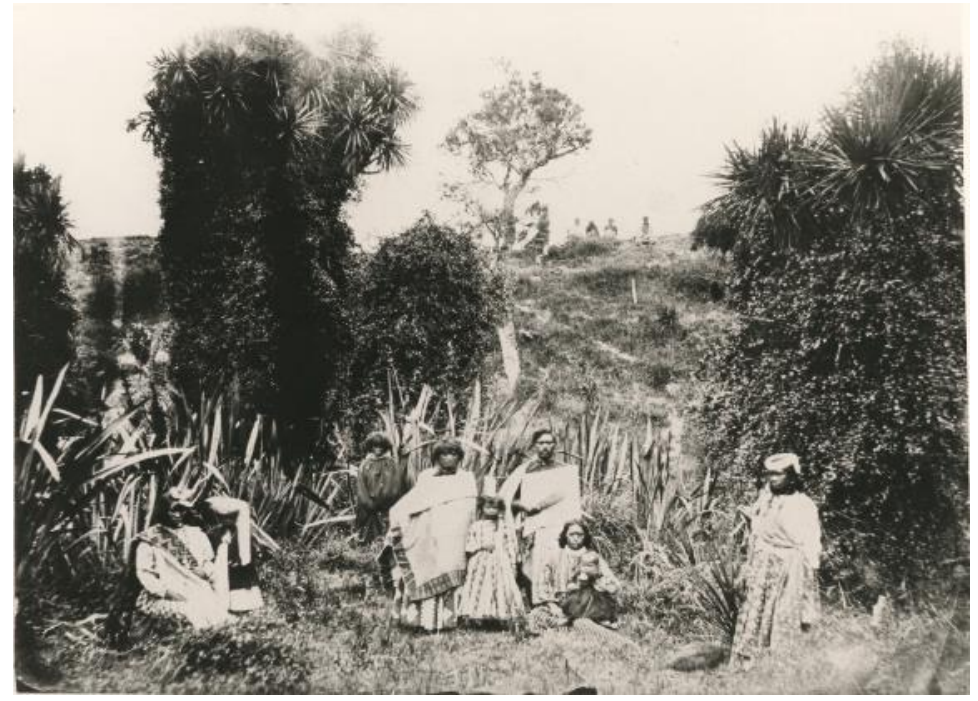

Figure 2: Te Heke (The Migration) to Omarama 1878. Source: Hocken Library, Asset ID 22772.

\section{Participants}

The first point of contact with potential participants, was to make contact with possible descendants from the original 150 tribal people on Te Heke 1877 via local iwi networks, including word of mouth, phone calls, emails, Facebook and Te Pānui 
Rūnaka Ngai Tahu tribal magazine. The names of interested people were gathered, and a group emailing list was compiled, with an introductory email sent to potential participants, explaining what the whānau journals research entailed. Approximately fifty people registered for Te Heke Omaramataka 2012, mainly drawn from the lower South Island, with approximately two thirds of the participants directly related through whakapapa, and one third connected through either a spouse or friendship relationship. Not everyone knew each other. The research data consisted of five kaumātua (aged over 55 years) and five adults (aged between $40-55$ ), comprising of five women and five men. Each participant kept a daily whanau journal over the four days of Te Heke Omaramataka 27 -30 th of December 2012. The researcher threaded the narratives together under the heading of each day, to provide an overall picture of the event, with participant quotes to illustrate a sense of belonging, context, space and time. It is also important to identify that the process of selecting which quotes would be included in a published paper, resulted in some narratives privileged over others. Within the research context, the role of the researcher was to gather the whānau journals, draw them together, and arrange the quotes so that the readers gets a feel sense of the participants experiences, including the synergies and differences between them.

\section{Whānau journals}

The aim of this research was to invite whanau to record in their own words their personal experience on Te Heke Omaramataka 2012. Each whānau journal consisted of twenty A5 pages, designed to be carried by each participant. The material provided within the whānau journals to participants comprised of three components; karakia, background information on the retracing the footsteps of Pōua Te Maihāroa and blank 'journal' pages with a border of Māori words and values such as: ahi kā ancestral fires, Papatūānuku, Rakinui Sky Father, whanaukataka, passive resistance, hapū, iwi, tīpuna, whānau, 
wairua, kaitiaki, kotahitaka. One of the front pages comprised of karakia for kai, sunrise and sunset. The following four pages of background information started by outlining the start, resting places and finish of Te Heke Omaramataka 2012, with the remaining text providing background information for participants. There were two points of data collection, one at the end of Te Heke Omaramataka on the $30^{\text {th }}$ of December 2012, and some journals were sent in within the following month. Ten whānau journals were received, then digitally transcribed, with transcriptions returned to each participant to check for accuracy. Once verified by the participant, each journal read as an individual narrative, to gain the essence of the experience for each writer. In order to maintain anonymity for the journalists, each whānau journal was assigned a coded letter from A-J. The ten texts were then divided into the four days of the event and placed under the heading of that day. The whannau journal entries were placed on in daily chronological order, from sunrise to sunset, to give the reader a reflective view of that day. Due to word limits and in the interest of the reader, not all of the journal information was included into this condensed article.

\section{Whānau Journals of Te Heke Omaramataka 2012}

\section{Waitaki River Mouth 26.12.2012}

The timeframe of $26^{\text {th }}-3^{\text {th }}$ of December, between just after Christmas and New Year 2012 dates, were chosen by the Te Heke Omaramataka 2012 steering committee, to encourage whānau and friends to join the walk over the summer holiday period when whanau were likely to be on annual leave. Whanau journals show that some participants had clear ideas and reasons for wanting to participate in this commemorative event. One elder identified an important intergenerational reason for the walk: "we have gathered whanau and supporters to make this journey so that in future, generations will be able to retrace Te Heke, having gained knowledge from this experience" 
(Participant J). The opportunity to honour the ancestors that undertook this journey was also echoed by Participant A: "The whakapapa behind Te Heke, the karaka of Aunty to take her whānau back into the hinterlands to visit the Hummock where our Tāua rests... a place of spiritual significance, for our whānau to experience together". This journal entry, reveals the multiple layers of whakapapa and acknowledgement of an ancestress that passed away at the Hummock (after being evicted from Omarama in 1879). This site was also poignant for another member:

"We stand, gaze across to old pine trees standing as a landmark sheltering the Urupa (graveyard) of our Great Poua (Te Maiharoa), Poua Taare and whanau who had been evicted from Te Aomarama in 1879, by legal process. It is a tearful time as we think of our whanau being threatened with Troopers carrying guns, burning down their thatched whare they had built two years prior, ie. 1877. Our Taua (Poua Te Maiharoa's hoa Wahine) has died up there and has been buried at the Hummock". (Participant J)

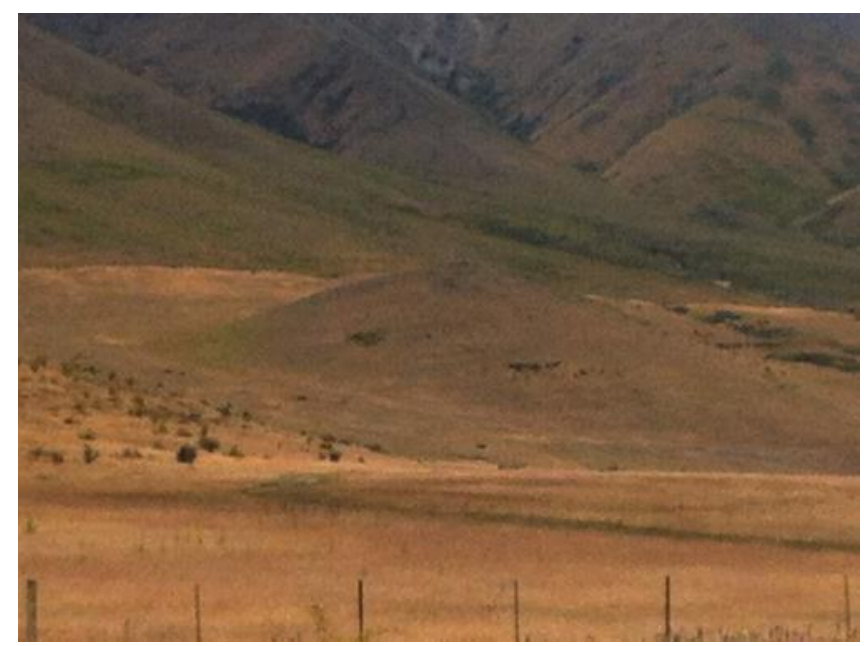

Figure 3: Te Poho o Te Rakitamau or locally known as Māori Hummock. The area where Te Maihāroa's wife, Kahuti is buried 
(Mikaere, 1988: 68 \& 141; Te Maihāroa, 1957: 38; Beattie, E-21: 12).

These accounts traverse across multiple time periods of time, from past and present reflections of this significant site, to future connections with mokopuna being able to learn from these trekkers experiences. It also reflects a multi-generational view of whānau, an Aunty calling to whānau to come together, and remembrance of a Tâua (Grandmother). Participant A indicates that Te Heke Omaramataka will be a spiritual journey for the "whānau to experience together". The referrals to the past, present and future generations create mental images that keep the memory of loved ones, and ones to come, close to mind and heart. A similar prediction was made by another journal writer, who also regarded Te Heke to be both a personal and collective spiritual journey. The following participant touches on the concept of rekindling ahi kā (ancestral fires), where partaking on the journey also invited the people of 1877 to venture alongside: "Before starting the journey I was aware that we would be laying a pathway of "Light" from the Waitaki river mouth to Oamarama and as the journey progressed I became aware of the whanau who were with us. The people and the horses were returning as we opened the pathway of 'Light', rekindling the fires that allowed them to travel back to Omaramataka”. (Participant B)

From these whānau journal entries, it seems apparent that there is a strong connection between the impending walk and remembrance of the tipuna that undertook this journey 135 years previously: "Poua was a Tohunga, with special powers he climbed a maunga, with fixed look he received a vision pointing out the ngutuawa of our Ancestral Awa Waitaki, as the wahi turanga to return with the whanau, which they did. Alas the ancestral whenua our Poua was taking the whanau to, unknowingly had been sized by the Government. Things had certainly changed, and we became strangers in our homeland". As whānau and friends assembled at the river mouth of the Waitaki River on Wednesday 26 th of December, Participant A, writes about the beauty of seeing familiar faces, the 
environment and the art pieces: "We arrive at the mouth. It is a beautiful place, and the stones make a sound like they are singing to you as you walk on them. I loved it instantly. There are several of the whānau members there, milling around. Several cars, vans and caravans. It feels good to see the familiar whānau faces, and I can't believe that we are finally here. The anticipation grows as the night grows. We are all interested in the beautiful rauemi that has been made for Te Heke".

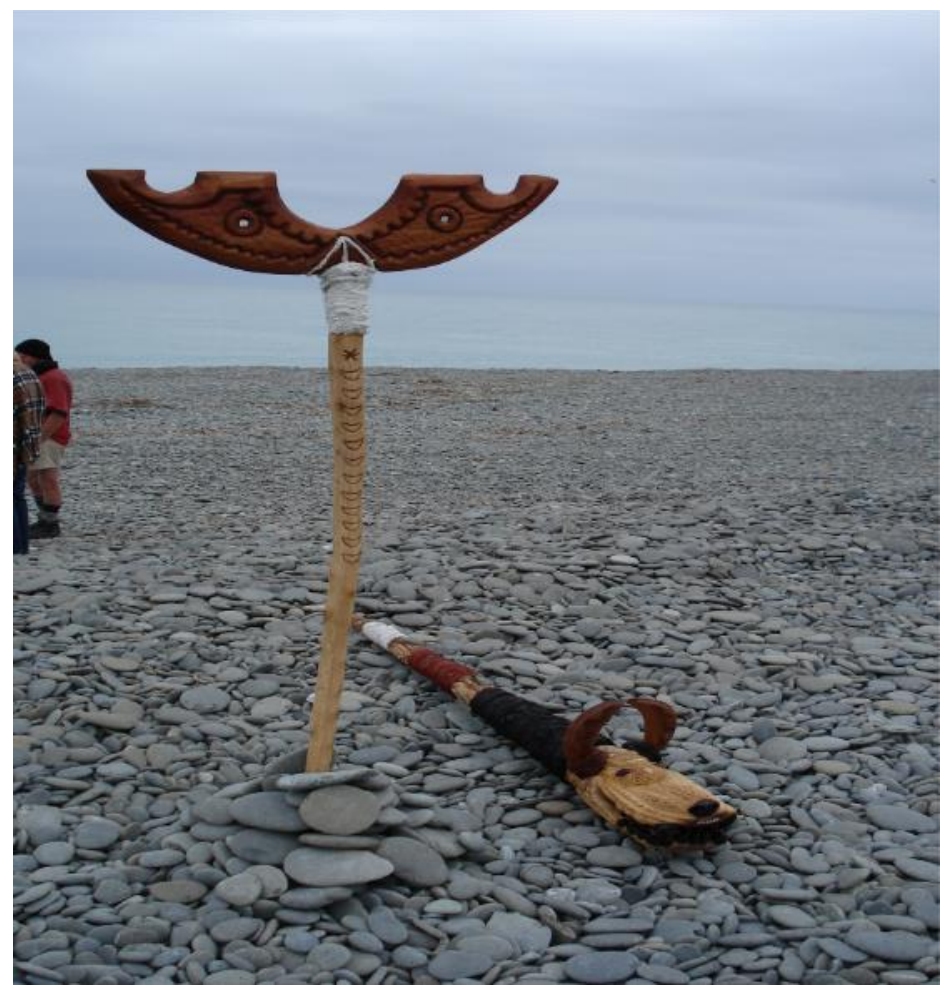

Figure 4: Two of the ceremonial pieces made especially for this event. 27th December 2012. Personal whānau collection.

The elaborate, ceremonial art piecse (Figure 4) were used at the beginning of Te Heke 2012. The time and dedication 
undertaken to make these pieces, were described by Participant E: "Arrived at the mouth of the Waitaki awa on the afternoon of the $26^{\text {th }}$ of December 2012. Had been very busy for many months prior, making special taonga for this heke. It was great to be here at last. Went and collected water from the river mouth for the hue, used another taha for this purpose". This whānau member had literally spent several months dedicated to making these taoka (treasures) to accompany the journey. The variety of resources from a bygone era, gathered and made from a bygone era especially for this occasion, seemed to prompt Participant $F$ to consider the differences between the contemporary and historical worlds: "We had a karakia at the Waitaki Mouth. Whānau got ready the lighting of the fungi that would take the fire from the mouth and finish off in Omarama. Whānau gathered water from the Waitaki Mouth in a gourd. It's at this time I realized that we live in a Pākehā world - our ancestors must have done life very hard. Time was not by a watch on their arm. We spent the night thinking and learning".

Another journal entry describes the beginning karakia, the roles assigned to male and female participants, and also where the fungi is from and the role of keepers: "The daughters of the fire-keeper ... (I) know that the ahi is in firm hands with these kotiro. There is excited talk as we marvel at the fungi (fungus that grows up the beech trees). Holes are made to keep the ahi embers. We talk about the kete that has been given to carry the fire - it looks amazing like a net of some sort. We head up to the river mouth for the sun setting / moon rising ceremony. The wahine say the karakia that says goodbye to the sun and the tane greet the rising moon". (Participant A). Fire is a common theme in the journal entries made on the first night, with one participant describing fire as 'ahi kā', perhaps referring to 'ancestral fires' rather than the other meaning of 'occupation rights', although they are both synonymous. "This is the Ahi Ka (the lit fire) when our Tupuna lived in the whenua, built their houses, cooked their Kai and left evidence of this in house sites, garden areas and hearth stones" (Participant J). The details 
required to keep the 'ahi kā' burning throughout the night and the fun shared trying to light the fire traditionally are also described:

"...next sourced fine sand for the ahi kaa, found a small deposit in the paddock by the campsite, filled up a kete. Then prepared ahi tāpu, upon the stony beach made a fire pit lined with kindling and wood, found a metal lid to maintain the heat and embers for the night. Brought some kauahi and hika (fire plough) to start the fire. Everyone had a go at trying to start fire by this ancient method, almost got it going - hot and smoking but had to light the fire the modern way in the end". (Participant E)

The challenge and enthusiasm of trying to light a fire the traditional way is expressed by Participant A, as a collective whānau effort: "There is great excitement as we try to light the fire with a piece of dry old tawa and a stick. We rub furiously for almost an hour. The whānau work and move as one, giving it all that we have, and taking over when we need a rest. Even the tamariki are getting into it and it reminds me of the skills that tippuna had to keep the ahi going". Another participant also recalled how the fire-lighting occasion also seemed to cement relationships between the members. Participant D describes both the literal warmth of lighting a fire, but also the warm atmosphere created by with karakia and waiata: "We all bonded as we tried to light the fire the traditional way - over a couple of hours we achieved heat and smoke but did not get a flame, this activity certainly warmed us. We lit the fire on the stony beach the modern way and in the light and warmth of the fire there was karakia and waiata. Whaea said karakia as the water was placed in the vessel to reflect and absorb the starlight". 


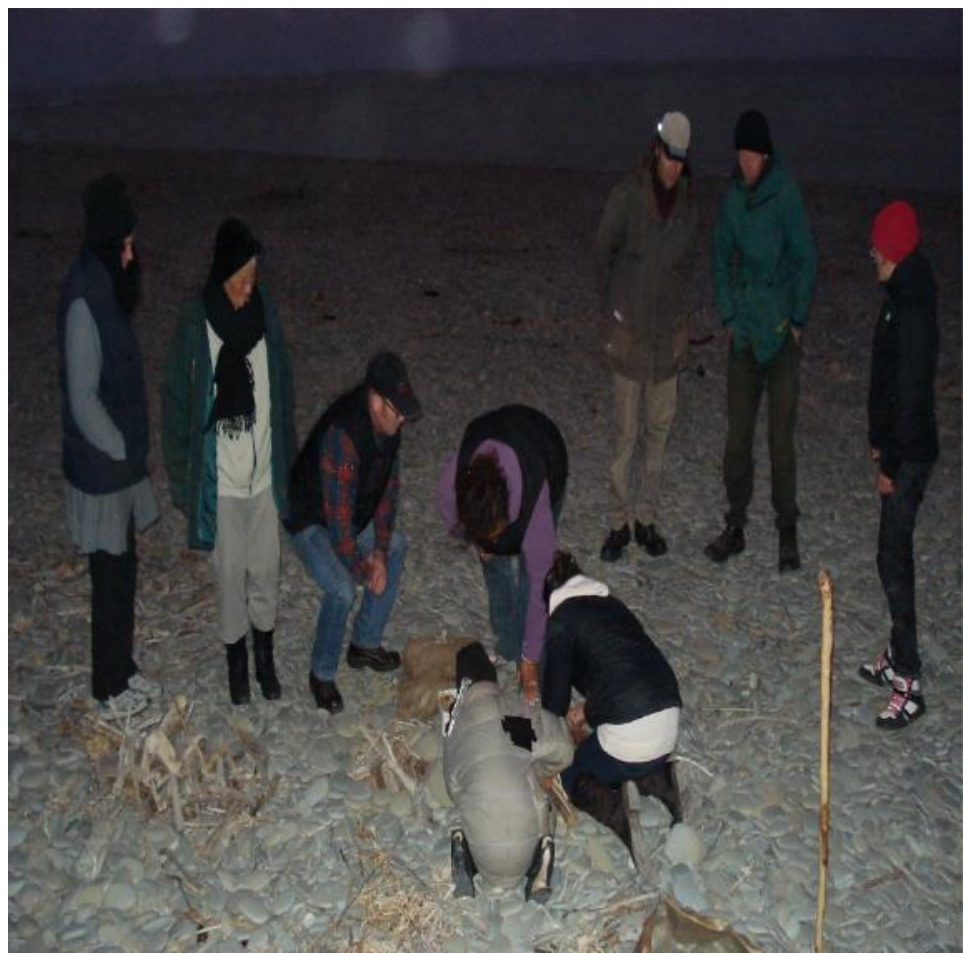

Figure 5: Lighting a fire the traditional way by rubbing two sticks together and one of the fire-keepers maintaining the fire embers the next morning. Waitaki River mouth. 26 \& 27 December 2012. Personal whānau collection.

The fire remained a focal point for the group, where several participants' journals touched on their own personal aspirations for the journey ahead and their ancestors: "I feel my tipuna around me, especially as the night creeps in. Now we are in darkness, sitting around the fire and sharing stories" (Participant A), with another member feeling "a sense of our Tupuna being near us, we feel their Wairua, we recall the kupu o aku waiata 'hoki mai e nga whanau I Te Ao nei' and 'See the Hawk soar above the mountain' brings us back to reality" (Participant J). The fire-side stories continued long into the 
night, with whānau listening to the experiences of elders and even contemplating a final resting place:

"We sat around the fire for what seems like hours, telling stories of the olden days and listening to tâua share her childhood memories of being of this whenua. We pay homage to our tippuna who lay in Korotuaheka urupa. I am reminded of the dilemma that I have contemplated previously, of where to be once I pass over - wanting my bones to lay with the bones of my people, but aware that council has changed the rules and now we can't even use our whānau urupa on Te Maihāroa road". (Participant A).

The thought of tipuna on the trails was also a thought for Participant J: “...as our people when they died were buried near where they stopped and marked with for example a stone fence where practical, or heaped earth". The night drew to a close, with a star ceremony conducted by a male elder. Again, the beauty of the resources made especially for this special time, attracted the attention of Participant A: "We embark of the star ceremony, and transfer the water of the Waitaki River mouth which is held in the hue, into the star bowl. The ipu is made from beautiful clay, specially sourced for this ceremony, with the white clay reflecting the stars and the moonlight. The opening ceremony is conducted in te reo Māori. It is ritualistic and haunting. The kōrero speaks about far off places and the names of our tippuna. The names of the tippuna on Te Heke have not been captured in entirety". The rituals carried out within the star ceremony welcomed the new day. This is explained by Participant E who briefly outlines the progression and energy expended: "The whānau gathered around the ahi tāpu, karakia were said. Next the water from the taha was poured into the ipu for the night stars to dance upon, karakia were woven into the waters followed by waiata. I was very fatigued following the creative build up by this stage and did not sleep well this night". 


\section{Waitaki to Duntroon 27.12.2012.}

As the whānau prepare for the initial leg of the walk, three whānau journals reflect on the night ceremony and lack or depth of sleep that night. Participant B attributed this period as a change of time of spiritual change: "There was a lot of pressure towards the end of 2012 with the change in the Mayan calendar from the stone calendar to the water calendar and in my life there were big changes. I had one hours sleep and out to the Waitaki River mouth by 5.50am. Good to get there in time for the ceremony. There was a feeling of the unknown as to what was going to happen and I felt comfortable in being there and had a strong commitment to the task ahead. Beautiful sounds have stayed with me from the opening the start of the journey and the sincere, honest words that were spoken at the ceremony". The dawn ceremony welcomed the new day and heralded the start of Te Heke Ōmāramataka 2012. Five participants described the dawn karakia, with Participant D noting: "waking after little sleep, the group gathered to welcome the sun and farewell the moon with karakia, and Participant B acknowledging that 'everyone welcomed the sunrise (all the women) and the men faced the other way saying goodbye to the moon, then we gathered around the small fire with our prayers". Whilst Participant E also recognised the greetings and farewells, a description of the mornings karakia was added: "greeted the sun, farewell the moon, Karakia of unfolding peace Pūkāea Anupini opened the way towards the mountains we began our long walk".

The dawn ceremony seemed to draw whānau members together, as they prepared to embark on an unknown journey. It was important to the group to honour the mauri of the Waitaki River and carry the water up through the valley. Three participants recalled the importance of carrying the water close to the heart. "A hue with Waitaki wai is enclosed in a smallish harakeke kete or basketry carried all of the journey ... to the stream at Aomarama" (Participant J). Participant E acknowledged that "the water from the ipu was placed in the 
hue tāpu carried against her heart in a rourou", and similarly, Participant D, greeted the process with honour "whaea said a karakia as the waters were poured into the hue for the journey, the pūkāea sounded, I harnessed the hue next to my heart and the journey began". Participant I also mentioned prayers recognising the significance of the ceremony, water and journey ahead: "Prayers were said and a leaving ceremony with singing and horns. The fire was lit and stored for the journey, water from the Waitaki Mouth was gathered, to be carried (up) to Omarama and placed in the Ahuriri River to once again mingle and flow back to the Waitaki mouth and the sea".

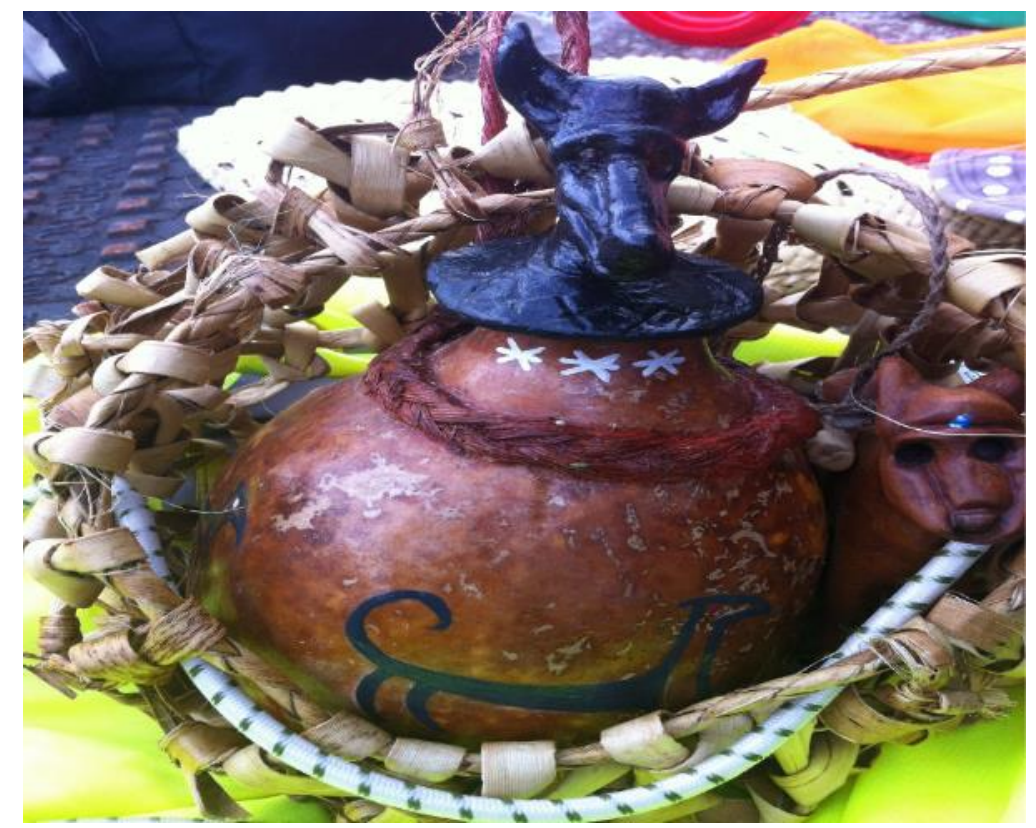

Figure 6: The 'hue tapu' the vessel that carried the sacred water from the mouth of the Waitaki River to the Ahuriri River. Omarama. 30 th December 2012. Personal whānau collection.

Preparation for the journey ahead included karakia for the primordial elements, as noted by Participant B: "Such a simple 
ceremony, but one with all the earths' elements included. The ceremony opened with sounding the conch shell, which was hauntingly beautiful". The transporting of the fire embers is another common theme, as Participant D describes how it will be carried amongst the walkers, "the fire carriers, placed the ember in the fungus in preparation for the day's journey - they plan to relay throughout the Heke". The finer details of the carried fire host is described by Participant E: "the Puku Tawhai - Beech Bracken fungus is burning the ember carrier, made a kōhanga in a net bag swung on a wero - fiercely it burned many times adjusting it on this day and on days to follow". Another walker, Participant D acknowledged that "tending to the smouldering ember meant we had to stop frequently to ensure it was not burning too fast or about to go out - this was a learning experience - it worked and each time we stopped to tend to this we noticed different things on the way".

The re-created traditional way of transporting and keeping the fire ember simmering, was novel and intriguing to not only the whānau, but also passers-by, as mentioned by Participant D: "Tourists and locals were fascinated by the smoke coming out of the woven kete on the end of a stick and stopped to ask us about it, others had passed us on the road and they asked us why we were walking". The water signified the mauri of the Waitaki River and the fire symbolized ahi kā roa (long burning ancestral fires of occupation). Participant E explains some of the roles and challenges as guardian of the earthly elements and spiritual wellbeing of the people:

"I tautoko the water and fire walkers all the way both in Te Ao Tangata me Te Ao Wairua. There were many challenges managing both these elements. The first walk was a physical challenge for most as this was the longest leg $40 \mathrm{~km}$. The support crew were much appreciated, feeding us, providing a wharepaku also. The faster walkers were ahead most of the time. Keeping an eye on the smouldering fire with dry grasses around was a constant vigil, so we went at a slower pace in our group. We bonded and had lots of laughing on our journey". 

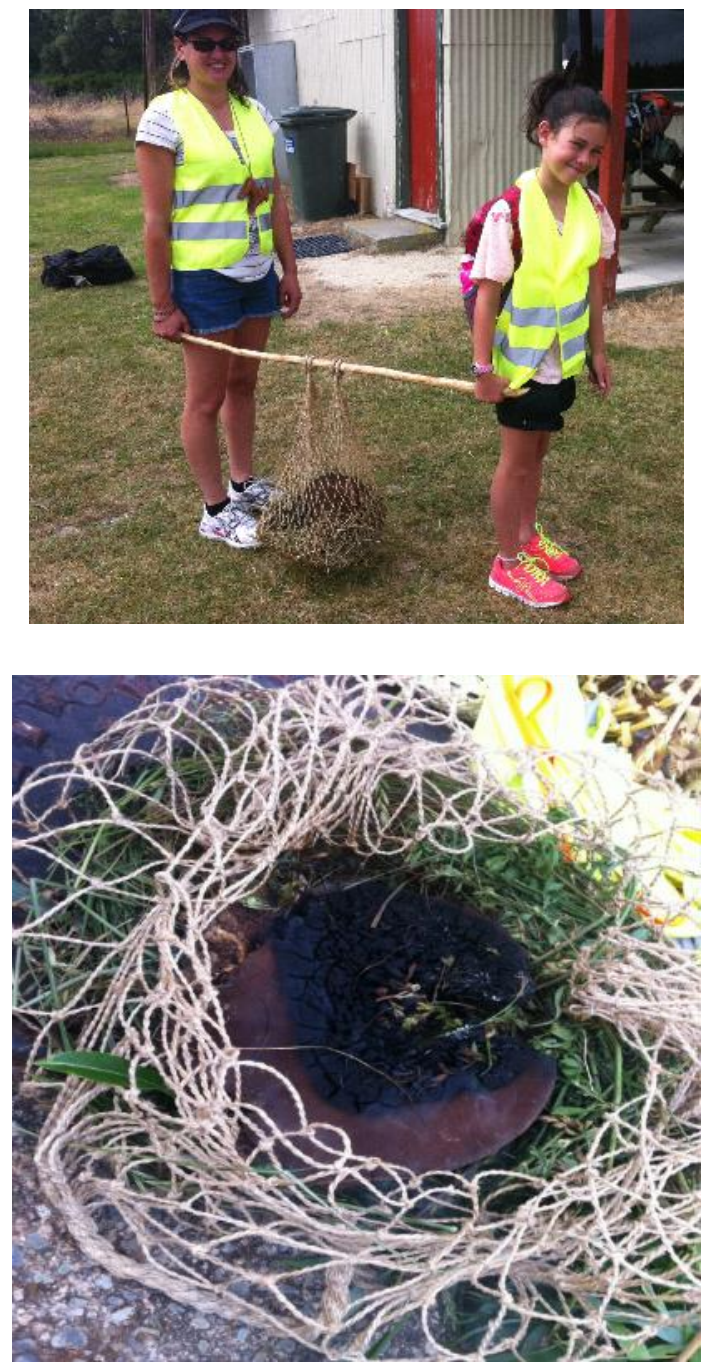

Figure 7: Two generations of fire carriers. The fire embers are maintained within the fungi, carried in a openly woven bag to let the air circulate and the remaining evidence of the fire embers that had been smouldering within the net bag. 28 December 2012. Duntroon. Personal whānau collection. 
The companionship between the walkers was noted by five participants. Participant I commented on "the camaraderie of the walkers and support crew" and Participant D observed "the weather was calm with high cloud, the majority of the day was walked off the main road, once we got onto the main road the traffic was fast and constant. Stories and histories were shared on the way". Participant $\mathrm{C}$, tallied "nine people were walking today with a rider behind, with a sign of warning to cars about 'walkers ahead' leaving plenty of room for cars to get around him, and the walkers ahead, on the other side of the road". Friendships were formed not only between the walkers, but also amongst the wider support crew, as described by Participant $\mathrm{H}$ : "we had an interesting time following the walk from the Waitaki mouth to Omarama Ahuriri River. We couldn't be there the whole time but enjoyed the company of the other people". Another walker, Participant I also walked and took on a support role when necessary: "I walked with my cousin most of the way to Duntroon. I rode some of the way with my Dad, as my feet were getting a bit sore. Had a catch up with the wonderful support crew. I cannot recall if I stayed long enough to greet all the walkers, but left to go home to Waimate as I had to work the next four days".

The support crew ensured that the walkers had the necessary resources to make the trek comfortable. Some journal entries were very practical, as noted by Participant G "Wednesday to deliver barbeque to whānau. Left on Thursday as support to walkers followed to Duntroon Domain. Helped set up then went home. Re-joined at Otematata for last day. Stayed at Omarama evening and left next morning". Similar to the relay of the smouldering fire embers between walkers, the support crew passed on moral support along the way, as described by Participant C 'two or three of the supporters' cars would stop to cheer them on, one car had a toilet in a trailer, and another had a caravan with food and water. I stopped with them along the way, to say 'hi' before heading to our next stop in Duntroon". One whānau member, Participant F, outlined the 
essential resources required for the following five days journey: "I am one of the Te Maihäroa's descendants and of Waitaha. Our journey started on the 26th of December at the Waitaki Mouth. We arrived with our Bus Mobile Home. My husband would be doing the journey for the first day. We had arranged a trailer that had a BBQ in it as it was carrying water and some food supplies".

As walkers arrived into the small township of Duntroon, some trekkers had been walking for twelve hours. The preparations for the night were both physical and spiritual, as noted by Participant D: "the fire carriers and our spiritual leader lit the nights fire from the ember and the Camp owner shared stories of fire carrying that he had heard and even provided wood to enable us to keep the small fire going and the embers hot until morning. I slept soundly". For Participant B, it was the realisation of guidance from a higher source:

"The first evening when we arrived in Duntroon I was surprised when the ancestors instructed me to anchor the 'Light' to a very large piece of pounamu that was in the shape of an anchor...The first day was a long one but easier for me on the bike. It was not until we reached the main road to Duntroon that I realized the full extent of my role in the stern of the waka. The faster walkers had gone ahead where they were in the prow of the waka, they were cutting through the (waves) energy finding the way and the sacred treasures and fire where in the middle of the waka where they were cared for by this group. I was happy in the stern looking after the safety aspect and looking after the spiritual whanau who were travelling up the road. They were with all of us but I was aware from previous journeys that the Waitaha always travel up the left hand side of the road or track".

\section{Duntroon to Kurow 28.12.2012.}

The following morning saw two of the walkers leave the group to re-join their family for the Christmas break. The following quote reflects the closeness developed over the previous day and 
the presence of each person as a 'gift': "The walkers started out about 9 am, after a ceremony and blessing around the camp fire, and in a circle of people giving thanks and saying goodbye to two brothers who had walked the first day and were moving on today. We all shared hugs and hongi (nose to nose, brow to brow greeting or farewell), wonderful!! Quite emotional. Anne thanked each person for their particular gifts that each one brought into this journey, during this circle, before the walkers left for this leg of the trip, this special pilgrimage". (Participant C) The historical significance of this area is commented by Participant J: "The Waitaki Valley is full of historic Maori place names, rock art shelters which were temporary places to stay, very few old ovens sites now visible, occasionally pounamu artefacts are still being found and gifted to our collection we hold". Just a few kilometres outside of Duntroon is Takiroa, an ancient site for Waitaha, consisting of limestone overhangs where tippuna took shelter and left a record of their experiences on the cliffs through rock art.

Although there are multiple interpretations of what the rock art depicts (O'Regan, 2007, 2003; Robert McDougall Art Gallery, 2010, Fomison, 1971; Trotter and McCulloch, 1971), the originators of the rock art has been ascribed to the first Polynesian travellers' and estimated to be at least 700 years old (NZ Herald, McAllister, March 2, 2013). Ngāi Tahu anthropologist Gerard O'Regan notes that the Takiroa rock art shelters containing 'archaeological evidence dating from the time of moa hunting' (O'Regan 2007, 418). Participant $J$ adds: "TAKIROA. Well known rock art site, a palce of special significance and important to us as Waitaha. Walking into these areas brings 'goose pimples', another world almost, for within the towering lime stone cave is a strong feeling of spirituality, which takes one back to an older period, it is as if the ghost of our Tupuna still exists and is watching over us, we feel that as a blessing". The significance of walking through this historic landscape was observed by Participant E: "going through the limestone lands of Māere Whenua was good for all 
the senses. We stopped at Takiroa and listened to Te pekepeke insects". Another walker, Participant D, remarked on the challenges the ancestors would have faced: "We stopped at Takiroa to acknowledge the Ancestors at the site of the Waitaha rock art. Our anchor man joins us on our short breaks as we tend to the ember and rest our feet... enjoying the scenery and reflecting on the Heke 135 years ago and how different the weather and terrain was then, the hardships they endured".

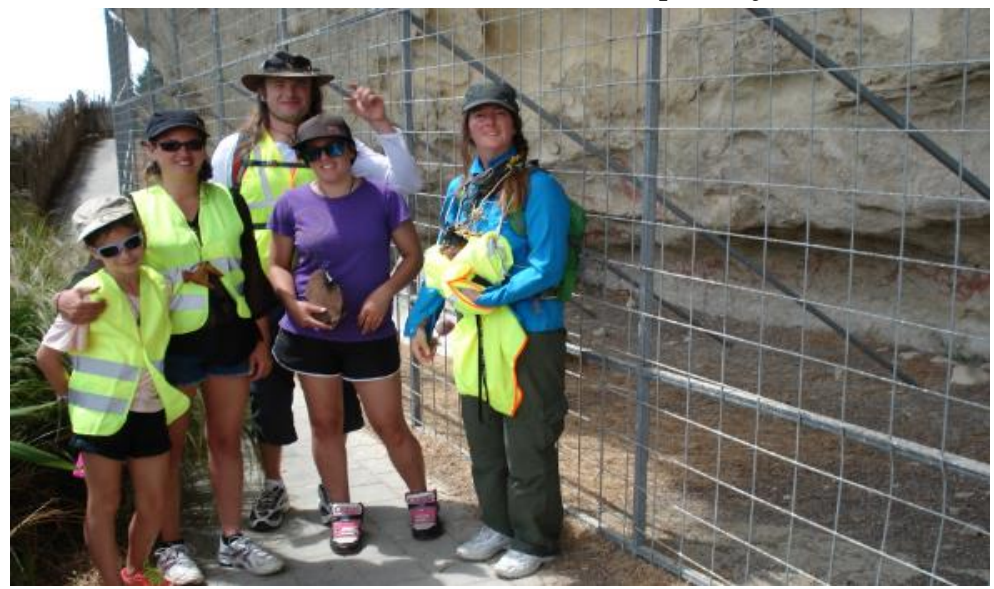

Figure 8: Some of the fire and water carriers in front of some of the protected rock art at Takiroa. 28 ${ }^{\text {th }}$ December 2012. Duntroon. Personal whānau collection.

One of the aims of Te Heke Ōmāramataka, was to honour the mana of the Waitaki River and supporting tributaries, as acknowledged by Participant D: "The fire ember was prepared, I carried the water hue, the day started with a good pace and plenty of energy, and we were all in good spirits. We said karakia as we crossed the waters - they look so sad and depleted". Although the participants who carried the fire and water talked about the honour of doing so, these tasks were also added responsibility and challenging. The continuous burning of the fire embers were also of concern, as identified by Participant E: “(I) lined the net bag with wet mud from clay I 
procured from the camping ground. Which I hoped would buffer the hot ember from burning through the net bag. I found I had to deduct some during the walk as it was too heavy. I enjoyed this walk to Te Kohurau".

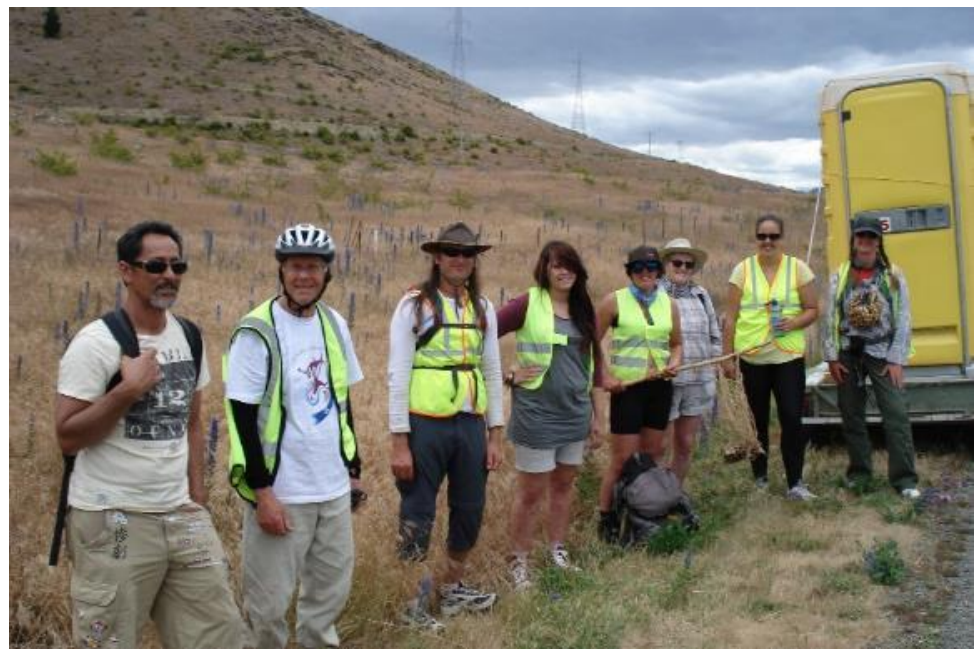

Figure 9: The popular 'yellow tardis', with whānau in a queue to visit the mobile port-a-loo. 28 $8^{\text {th }}$ December 2012. Otematata. Personal whānau collection.

The physical environment also posed a challenge, both in terms of cars and the temperature. As the walk was over one of the busiest weeks of the year, between Christmas and New Year, and the roads can be long and straight, Participant $\mathrm{C}$ wrote about her concerns for the safety of the walkers and the biker: "We moved on ... (where) it was safe to park and allow room for the walkers and (the biker) to relax for a short break. Many cars on the road today, a bit worrying for bike riding, not really enough bitumen to ride on safely, between the white lines and the grass verge". In the early afternoon on the second day, a local reporter from the Otago Daily Times caught up with the walkers, as noted by Participant E: "An Otago Daily reporter came and took a photo of the fire and water walkers and young 
kotiro' and Participant D: 'We had our photo taken for an article in the ODT". As it was another long day's walk of up to twelve hours, Participant D recalled how encouragement and small indulgences helped to break up the journey: "We stopped for a coffee and an ice cream at Kohurau - little treats really enjoyed... Te Kohurau Museum people drove to greet us and encourage us on".Walkers sheltered in whānau caravans dotted along the route to rehydrate and eat some food. The fierce determination was shown by Participant $\mathrm{D}$, who described the harsh walking conditions:

"We lunched under a large tree and were joined by friends, we had a foot and leg massage - sooooo good! I had developed shin splints and blisters, my legs were so swollen - I haven't had this before - it was great to take the shoes off for a while. HOT HOT HOT! Sun is intense today! Each step was agony for me for $3 / 4$ of the day, but I was determined to walk the entire journey. Again our support crew helped us along the way with kai, toilet and telling us how much further we had to go... The yellow Tardis port-a-loo was a welcome sight as this meant a brief spell and a friendly face". 


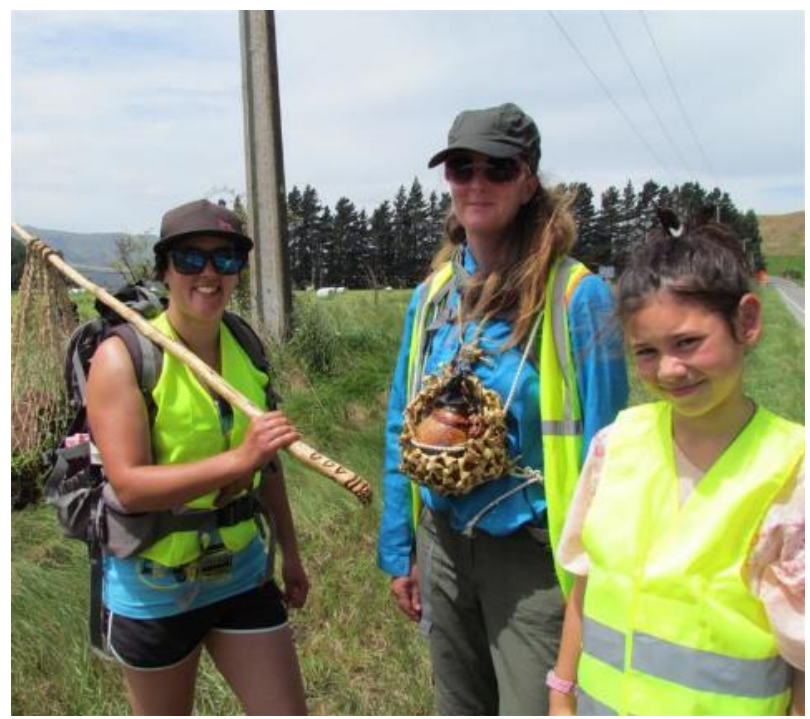

Figure 10: Carrying the sacred waters from the Waitaki River mouth back to the Ahuriru River, during a heke to remember their ancestor Te Maiharoa. 28 $8^{\text {th }}$ December 2012. Otago Daily Times, 2 January 2013. Photo by Andrew Ashton.

The Kurow Museum holds some special Waitaha taoka and has a close relationship with the Waitaha people. As some of the walkers arrived into Kurow, there seemed a special welcome for them, as observed by Participant D: "The evening light was beautiful walking into Kohurau, the air was still and warm until we walked past the museum a breeze momentarily blew and the Waitaha Grandmother Flag at the Museum flew fully open to greet us into Kohurau". The warm atmosphere and tidy amenities were appreciated by tired walkers and supporters, as pointed out by Participant C: "We headed into Kurow, nice little town into the camping ground, a well-organized area, tidy and inviting, clean facilities - toilets, showers and kitchen area. The last of the walkers and rider came in around $8.30 \mathrm{pm}$ ". The evening provided a much needed rest for the walkers and supporters, although the moon and stars seemed to put on a show as mentioned by Participant D: "we joined the rest of the 
team at the camping ground and slept well under a full moon" and Participant E added: "Adapted the fire placing it in a ceramic pot then off to bed. The stars shone and Rākinui bathed the whenua in a silver korowai as Pareārau pulsed in the heavens". One of the spiritual leaders, Participant B revealed: "The second and third night the people and 'Light' were anchored and held by the camping Waitaha group. From my previous journeys I have made and journeys I have done, I am aware that there are protocols to be respected when moving with Waitaha, the Ancestors and Ancient Ones".

\section{Kurow to Otematata 29.12.2012.}

The days for both walkers and supporters were long, with karakia beginning at sunrise and concluding the nights around midnight. Walkers tried to get on the road early as to get some kilometres behind them before the intense parts of the days heat, as recorded by Participant C: "We arose early around 7am, have to get on the road early today, it's going to be hot today and the walkers will need to use their fresh energy to move along the highway towards Otematata camping ground". The energy seemed to be high this day with two participants noting the speed of the walkers as they moved through the valley, with Participant C, recording "I met the walkers around 10.20, they had done approx.. $10 \mathrm{kms}$ by then and doing well, the $1^{\text {st }}$ group had done about $15 \mathrm{kms}$ " and Participant D also detailing the early progress: "Again the day began with good energy and enthusiasm in our steps, a good pace was set. The traffic was full on today"! After three long days of walking up through the Waitaki Valley alongside speeding cars, rests with the support crew were valued and appreciated, as recorded by Participant B: "I did enjoy the chats along the road when we stopped and sat as a group having a rest on the trail. I think that everyone worked very well together, the support people and the walkers and the people on the road could feel this support from the whanau". Participant $\mathrm{C}$ described the trekkers as 'our brave walkers', whilst also acknowledging the support biker: "One 
person came in behind the last few walkers, on his bike, holding up the rear (or stern of the waka) whilst another pulled in for a chat, before heading further up the road, climbing steadily higher and getting more tiring for our walking whanau". The significance of the journey was a heart-felt connection for Participant B: "There are so many aspects and there seemed to be a lot going on, with many levels of activity. I remember biking along quietly and thinking about the ancestors, the whanau following us up the road with their horses and belongings and thought to myself, 'this is huge what we are doing' and the tears were flowing down my face as they are now as I type this. It is very close to my heart and the people have been able to return to their true home in the mountains were Te Maihāroa took them. It was good to see how everyone's skills blended together to create a successful and safe journey".

This stretch of the walk alongside Lake Aviemore, prompted two journal entries about the majesty of the surroundings. Participant $\mathrm{C}$ detailed the "beautiful views of the lakes system and mountains are seen from this area, now with layers of misty blues and mauves of the higher mountains in looming up behind them, some still with snow". For Participant D, the picturesque scenery was enhanced with the company of some new walkers: "others joined us throughout the day which was great. A long walk, lovely views of hills and lakes, we went for a swim when we reached camp very refreshing ". Another whānau member, Participant B, also noted the company and support: "I did enjoy the chats along the road when we stopped and sat as a group having a rest on the trail. I think that everyone worked very well together, the support people and the walkers and the people on the road could feel this support from the whanau". By the end of another long day trekking in the heat, the walkers were physically put to the test once again. Participant $\mathrm{C}$ offered extra support to some of the participants: "The walkers finally got in at $9 \mathrm{pm}$. I gave a massage and healing to those with sore legs - very sore! It was blowing up a storm, we couldn't get any tent pegs into the ground securely, so hoped 
the tent would say up through the night... Everyone enjoyed a 'hangi' for dinner". The kai was appreciated also by Participant D: "had a nourishing meal and slept intermittently as it was a noisy and full campground at Otematata", with the desire for sleep winning over company of others for one whānau member: "joining with the whole group in the evening did not happen for me as it was getting late by the time we put up the tent and prepared food. Tired and just wanted to get to bed". (Participant B)

\section{Otematata to Omarama 30.12.2012.}

This is the last day of walking, bringing a special surprise to those that rose early, as mentioned by Participant E: "Woke up before sunrise, showered, did yoga and said karakia with tōku porotiti, prepared. A beautiful double rainbow rose out of the mountains - it began to gently rain". Although Participant C probably welcomed the addition of rain to a dry campsite: "It rained heavily all night and into today. The fire siren rang after going to bed last night and we could see some flames next to us, about 15 mins later, but it was the fire-keepers keeping the tradition of lighting a fire at each camp site and we hadn't had one last evening - someone had bought the 'hangi' in - so no fire had been lit for cooking. The girls had done to bed and realized that they needed to have a little fire between our tents - in a small saucepan - so not too much to worry about - phew"!! Rain was a common theme on this last day, with Participant $\mathrm{C}$ identifying the extra challenges of packing up a sodden campsite: "Rained heavily, only short periods of lighter raid, but got extremely wet packing up our tent and car, just getting the tent pegs out of the ground and roughly folding a saturated tent and lifting it up into the pod on the roof of the car was an effort... Caught up with the walkers and their guardian at the rear". It seemed that the rain forced the walkers to bow their heads and be present, focusing just on the next step. Participant D made the following connections: "It was raining very heavily all morning and it was very cold as we trekked on up over the hill 
- Heads down under rain hats and I noticed we were literally walking in each other's footsteps as we chanted and sang to the pace of our footsteps along the way".

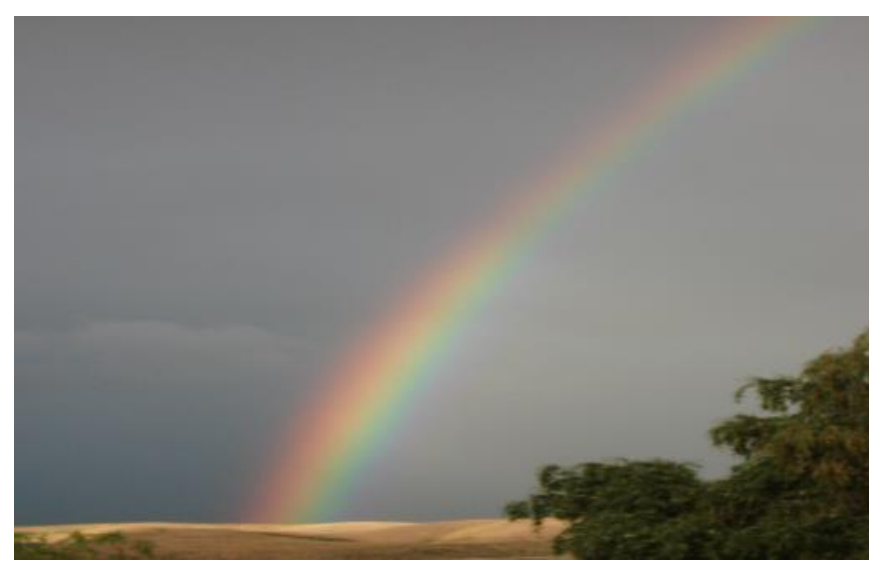

Figure 11: A 'tohu' interpreted as a sign by the whānau that our tippuna were happy with our accomplishments. 30 ${ }^{\text {th }}$ December 2012.

Otematata. Personal whānau collection.

The cold, wet weather of the last day, didn't seem to deter the high spirit of the walkers. As noted by Participant E, the addition of new whānau members seemed to invigorate the collective atmosphere: "(our cousin) joined our small group, we made good speed with new energy - the rain was heavy and it was very cold as we ascended the hill crossing the pass - we got soaked to the skin". Another member, Participant C noted: “...such a beautiful scenery through here and I'm really recognising what a special pilgrimage / journey that we are all on - the carrying of the waters and the fire: the wind helping to move us along the way (the winds of change?) and the connection of feet to earth and treading softly - reconnecting to our earth mother - was so profound". The connection between the changing earthly elements, the natural environment and those walking the landscape, seemed to contribute towards a feeling of support and appreciation: "The wild flowers were 
bright and beautiful in these stormy light, droplets of water glistened on the foliage. We stopped ... for a hot cup of tea and kai, this was very welcomed. We put on warm dry clothes and set off again - a bigger group now" (Participant D). This welcoming of dry clothes and hot tea was also echoed by Participant E: "Stopped at Sailors Cutting and changed our clothes to dry ones, had a hot cup of tea and some lunch thanks to whanau camped there, whom then joined us for the walk and the sun came out warming us on the rest of the heke to Omarama".

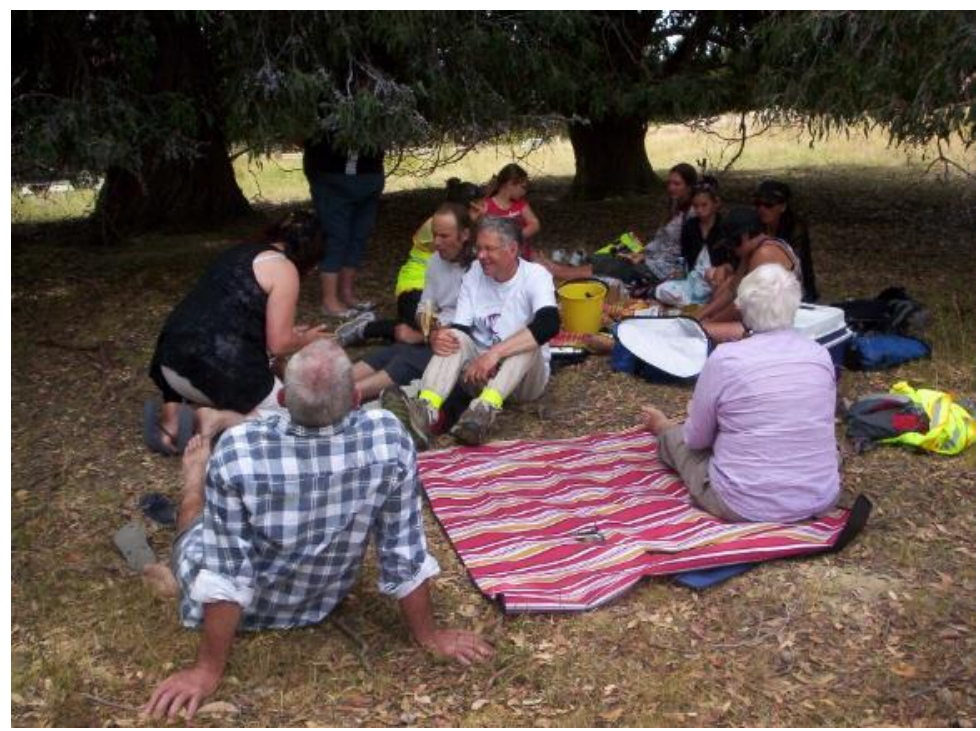

Figure 12: Whānau enjoying a picnic together, after a morning of rain. 30th December 2012. Otematata. Personal whānau collection.

Now dry and re-energised, the whānau pushed on towards Ōmārama: "Energy was fluid as we made our way to Omarama. Beautiful scenery, karakia to the waters and the birds all the way. Arrived at Prohibition road, all the walkers linked up and came to the Awa Ahuriri together" (Participant E). There ambiance certainly moved from the challenge of completing the 
walk, to a feeling of achievement: "(I'm) just feeling this energy of those who have taken part in this walk, their pain, their companionship with each other, their tears and tiredness, their strong resolve touched my heart and soul so deeply... I have learnt so much, on so many levels of my being. A very big thank-you for your acceptance of me into your whanau"(Participant C). Just after midday, the walkers had broken through the worst of the weather, with the rain clouds lifting to show the spectacular Waitaki River basin, now laid out behind them. The participants were now reflecting on this experience:

"The group continued to grow in numbers, we arrived at the Ahuriri River in Omarama. We distributed flags and instruments amongst the walkers, we walked the last footsteps to the ceremony where the elders were gathered. We were all exhausted from the physical journey we had just done over the past days. This was an emotional moment as the culmination of the experiences and memories of those before us came to the fore" (Participant D).

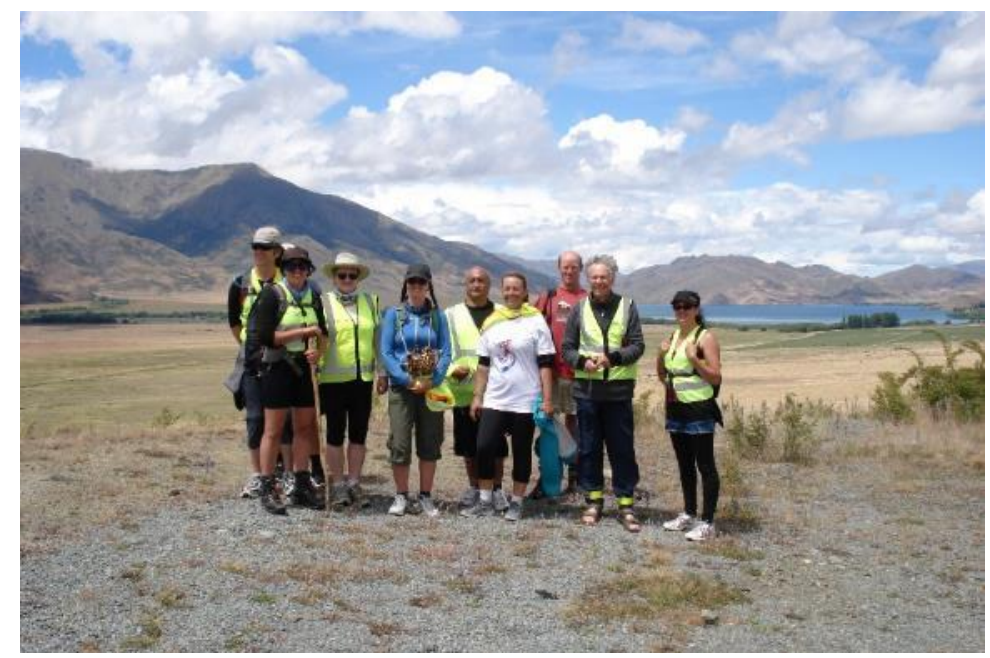




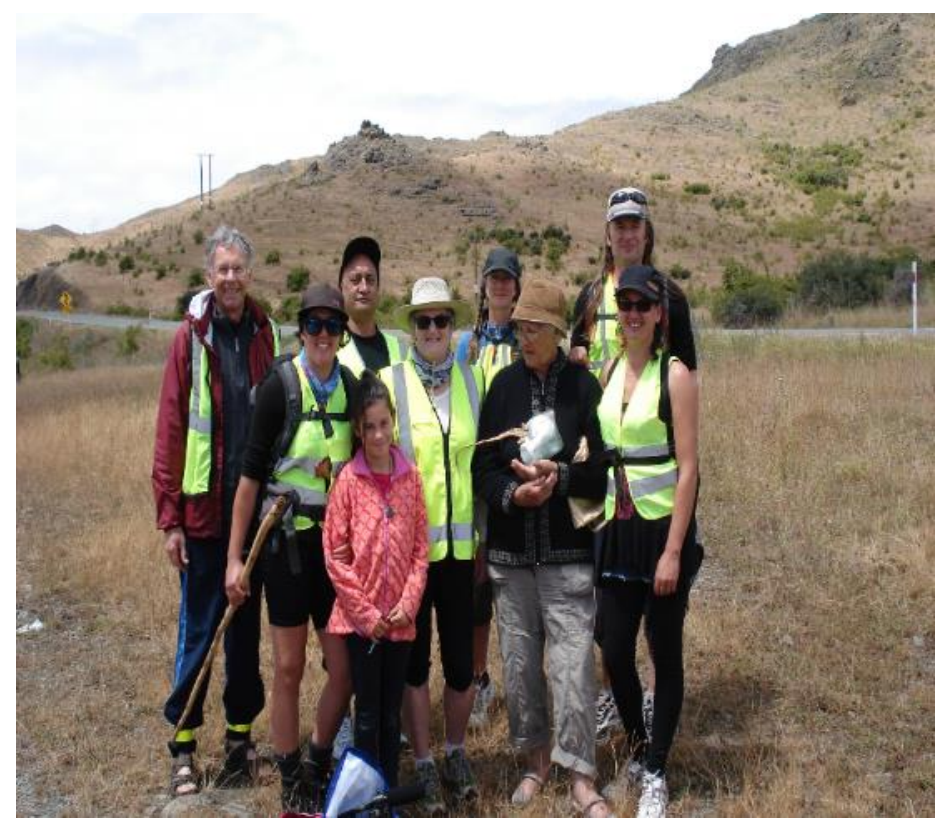

Figure 13: These two photographs capture whānau at the top and bottom of the pass near Prohibition Road, Ōmārama. 30 December 2012. Personal whānau collection.

The opportunity to follow the footsteps of ancestors was more than just a physical and emotional challenge. It created the occasion for not only kin, but also like-minded people to come together: "Coming into contact with Waitaha spiritual Ancestors was very natural for me and over a number of years there were a lot of journeys under their direction... Te Heke was a journey with family and I felt enfolded by the whānau" (Participant B). The whānau experience on Te Heke was also celebrated by another member:

"The circle of family, the wonderful 'invitation' to join the family, by one of the grandmothers and greetings from the spiritual leader and sharing of the story of the original walk of the Waitaha people from the Waitaki river mouth - (great 
grandfather and his families) the words and feelings expressed by several locals to the existing families of the Waitaha peoples, of apology for the ill treatment and sorrow inflicted on these peaceful peoples" (Participant C).

The quote above represents the only member to write about the historical grief and loss associated with Te Heke 1877, (although it is quite possible that other whānau journalists may have experienced a mixture of feelings, no other sorrowful memories were recorded). Participants recalled the closing ceremony as 'sacred, honourable, beautiful and extraordinary. "The ceremony was a moving occasion with histories acknowledged, karakia and waiata, the water from the hue was returned to the spring and the fire to the earth with karakia from our Matriarchs" (Participant, D). Another member wrote that "It was an honour for me to be asked to sit in the front at the ceremony and when I sat in the chair I felt a very strong energy around me ... It was beautiful to experience this, to feel the depth of it" (Participant B). The following journal documented in detail the unfolding ceremony:

"Distributed nga haki and taonga puoro amongst the walkers. Carried a kete containing pumoa blew a hue puruhau to clear the way for the walkers to the powhiri. Young kotiro blew the pūpakapaka also. Met Kaumātua at the puna, speakers spoke on both sides Korimako, Whekau, Riroriro, Pīpipi, Mohua, Pouakai, Pūngāwerewere were some of the rhythms, Aroha hou Te Rongo was the outcome. Then took the wai tāpu and ahi tāpu to the puna Waitaha kawe Wai Taha, Waitaha tiaki Rānui- mission completed. $135 \mathrm{~km}, 135$ years since the last heke, that we honouring" (Participant, E). 


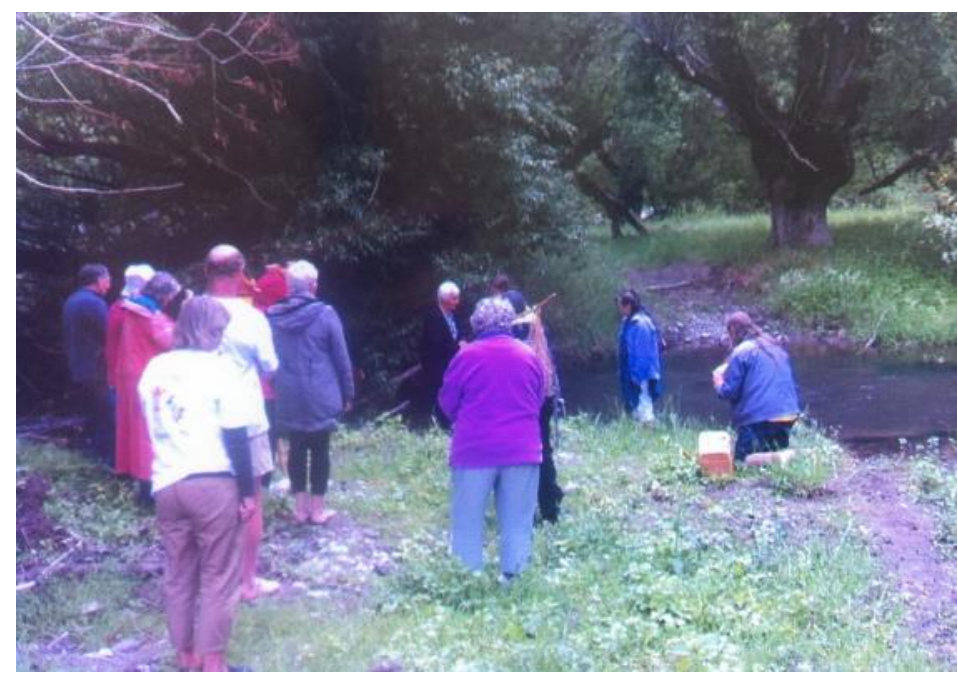

Figure 14: The end of the closing ceremony, where the water carried from the mouth of the Waitaki River was returned to the Ahuriri

Stream. Omarama. $30^{\text {th }}$ December 2012. Personal whānau collection.

For one participant, the late arrival on the last leg of Te Heke acknowledged a missed opportunity: "Whānau had taken our bus for the last part of the journey too. My husband and I are both descendants of Te Maihāroa, yeah. On my return there were lots of tales to be told. I missed a fantastic journey. The nights my whānau spent all together, walking, riding, eating" (Participant F). Others felt that the ancestors were pleased with the actions undertaken: "We have blessed Papatūānuku and her sacred waters, sea and sky with our actions and the Waitaha people are very happy to be back in Omarmataka" (Participant B). The wairua had been rekindled through the valley once again:

"The water from the mouth of the Waitaki river was released from the special gourd into the Ahuriri river, a sacred area where the Waitaha people had lived. The fire which was carried, quietly keep alight, along the journey was lit from the original 
fire on the foreshore at the start of this walk (sacred fire and prayer over) from the river-mouth to the mountains, taking with light with them, this was put into the earth near the stream anchoring the energy of the peoples, their spirits, and their strength through their journey" (Participant C).

\section{Conclusion}

As captured within these whānau journals, the retracing of ancestral footsteps has been a moving experience for all of the participants on Te Heke Ōmāramataka 2012, completing the two whānau goals of commemorating Te Maihāroa and Te Heke (1877) and honouring the mauri of the Waitaki River. One member, Participant D, felt that the group had honoured the tipuna: "We did this to the best of our abilities in the modern day with our limited knowledge - we learnt a lot during the preparation and walking of the Heke. What an honour to participate in this Heke". Te Heke Ōmāramataka 2012 was a heart-felt experience, weaving together connections between whānau and the landscape, and a trail of personal experiences entwined in whānau journals for future mokopuna. These memoirs highlight the strength of whānau connections, of not just those present on the trails, but also a time to honour those that have walked the trail hundreds of years before, and ngā atua, the origin of all things past, present and future:

"We were all sore $\&$ blistered at the end yet it was an honour $\&$ a privilege to be part of such a tapu journey, to Whetū Hīkoi in the many great cycles of heke ki te Te Ao Mārama. Tēnā Koutou Katoa to everyone involved in making this happen. Waitaha Nga Kaitiaki o te Korowai o Rongo Marae Roa, Kaitiaki Matua o Nga Tatau o Te Rangimarie me te ora, Fire, rain, wind and snow followed - blessings from Nga Atua" (Participant E). 


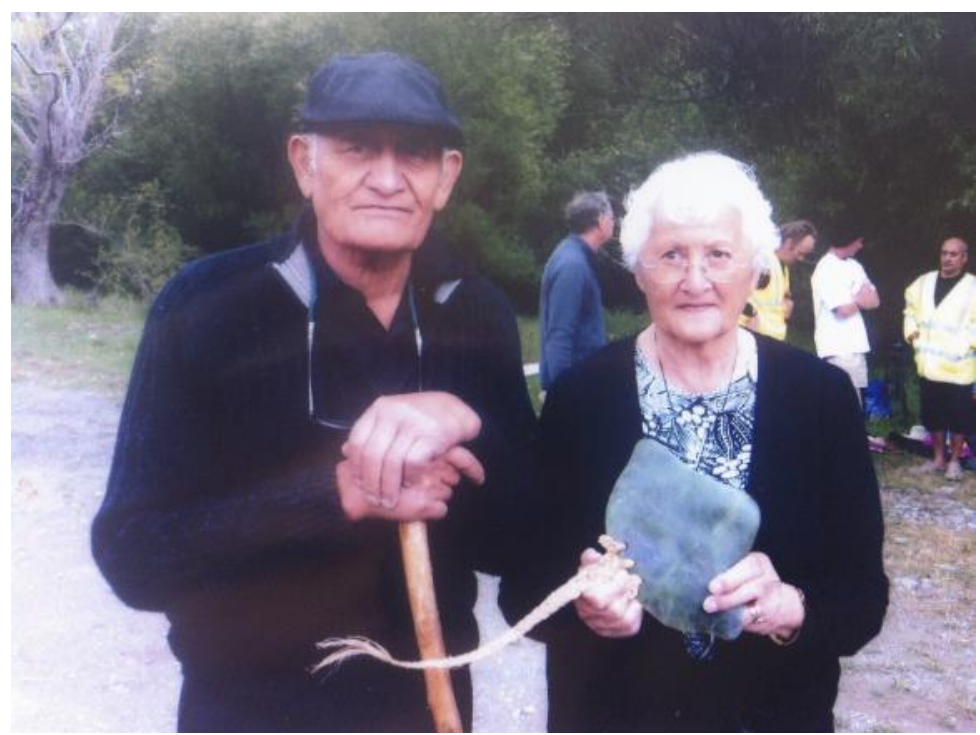

Figure 15: Upoko Rangimarie Te Maiharoa and Tumuaki Anne Te Maiharoa Dodds. Omarama 30th December. Private whanau collection.

The participants experiences align with the documented voices of other whānau, hapu and iwi that have also chosen to reconnect with their tippuna in a similar journey (Te Kanawa, 2016; Napier, 2013; Forbes, 2016; Te Karere, 2016; Joseph, 2012; Smith, 2016). These journeys inform us of a sense of spiritual undertaking, a reconnection with the past, present and future by following in the footsteps of ancestors to commemorate and keep their memories alive. For the descendants of ancestors forcefully taken from their ancestral land and made to work under enforced labour, the experiences can be emotional, stirring up old memories and brings to the forefront the pain that the tipuna suffered (Smith, 2016; Te Maihāroa, R. in Judge, 2012). The participatory experience of walking in ancestral footsteps therefore becomes an intimate intergenerational encounter of the body, mind and soul.

The walk of 135 kilometres over four days, from the sea to 
the mountains, each kilometre corresponding with a year that had passed since the original trek. The experience of retracing the footsteps of tipuna is possibly one that is cannot be erased from our body, memory or consciousness. The time spent in preparation of Te Heke, the journey itself and the points of reflection, provide bountiful gifts from this significant occasion. "Tuku tō ngākau, tō wairua, tō ihi mauri. Kia rere purehua ai, mai te moana ki nga maunga tu tonu. Te Heke Omaramataka will once again relight ahi kā that Te Maiharoa maintained during Te Heke" (Ruka, 2012). At the end of this walk, the whānau agreed that Te Heke should be undertaken more regularly, as a peace march to preserve the wairua of the Waitaki River, the memory of tipuna, and the heartbeat of the Waitaha people. As described in many of the whānau journals presented within this paper, Te Heke Ōmāramataka 2012 was a life-changing experience:

"We are different people from the persons who started this journey as we have been enriched by the learning and the experience of the journey. The time was right for this to happen and it was completed with the respect and grace to our Ancestors, Aoraki, the Guardians of the Waitakai River and sacred places. We have much to learn and it is a wonderful experience to learn within the framework of Waitaha whanau and the world about them. Waitaha is the Twelfth Nation of Peace and this is where we stand in our Truth. I feel that Te Maihāroa is well pleased with our efforts and that this is a new journey for Waitaha. The opening of the pathway from the Waitaki River Mouth to allow Te Maihāroa and his people to return to Omaramataka and the opening of the pathway for Waitaha". (Participant B) 


\section{References}

Andrew, C. (2016). ANSTO Report (unpublished).

Beattie, H. Beattie Collection 1939-1945 (ARC-0162), Hocken Library.

Bishop, R. (1996). Collaborative research stories; whakawhanaungatanga. Palmerston North: Dunmore Press.

Bishop, R. (2005). Freeing ourselves from neo-colonial domination in research: A kaupapa Māori approach to creating knowledge. In N.K. Denzin \& Y.S. Lincoln (Eds.), The Sage handbook of qualitative research (3rd ed., pp. 109-138). Thousand Oaks, CA: Sage.

Devere, H., Te Maihāroa, K., Solomon, M. \& Wharehoka, M. (2016). Regeneration of Indigenous Peace Traditions in Aotearoa New Zealand. In Devere, H., Te Maihāroa, K \& Synott, J. (Eds.). Peacebuilding and the Rights of Indigenous Peoples: Experiences and Strategies for the $21^{\text {st }}$ Century. Springer.

Fomison, T. (1971). MS-0928. Photocopies and sketches. Hocken Library.

Fomison, T. Tony Fomison Notebooks, Auckland Art Gallery, RC 2009/8/3/3).

Mead, H. (2003). Tikanga Māori: Living by Māori values. Wellington: Huia.

Mikaere, B. 1988. Te Maiharoa and the Promised Land. Auckland: Heinemann Publishers.

O'Regan, G. 1994. Caring for rock art. NZ Historic Places 50:27-28.

O'Regan, G. 2007. The shifting place of Ngai Tahu rock art. In Islands of inquiry: colonisation, seafaring and the archeology of maritime landscapes. Eds. O'Connor, S., Clark, G. and Leach, F. ANU E Press.

Royal, C. (1998a). Te Ao Marama: a research paradigm. Paper at Te Oru Rangihau Maori Research and Development Conference. Massey University, Palmerston North, New Zealand.

Rosenberg, E. (1994). The Geography of Memory: Walking as Remembrance. Landscape Journal, 13(2), 139-144.

Smith, G. (1997). The development of Kaupapa Māori: Theory and Praxis. Unpublished $\mathrm{PhD}$ thesis, The University of Auckland. Auckland: New Zealand.

Te Maihāroa, K. Kaore I te Whakaheke Toto (Do Not Shed Blood): Looking into the Past for messages to create a Peace Based Future. In Pim \& Dhakal (Eds.). Nonkilling Spiritual Traditions. Centre for Global Non-Killing: Honolulu.

Trotter, M. and McCulloch, B. (1971). Prehistoric Rock Art in New Zealand. Reed. Wellington.

Tuhiwai Smith, L. (1999). Decolonising methodologies: Research and indigenous peoples. New York: Zed Books \& Dunedin: Otago University Press.

\section{Personal Communication}

Te Maihāroa, R. (2013). Personal interview. Omārama, April 2013.

Ruka, P. (2012). Personal email. December 2012. 


\section{Online References}

Ashton, A. Ancestral journey retraced. 2 January 2013. Otago Daily Times. https://www.odt.co.nz/regions/north-otago/ancestraljourney-retraced (accessed 10 November 2016).

Forbes, M. Warriors retrace footsteps of Chief Te Ruki Kawiti. 10 January 2016. Radio New Zealand. http://www.radionz.co.nz/news/te-manukorihi/293821/warriors-retrace-chief's-footsteps (accessed 10 November 2016).

Napier, L. Chiefs retrace footsteps of Tainui in region. 20 January 2013. Stuff.co.nz. http://www.stuff.co.nz/sport/rugby/superrugby/8199530/Chiefs-retrace-footsteps-of-Tainui-in-region (accessed 10 November 2016)

Maori Rock Drawing The Theo Schoon Interpretations, Robert McDougall Art Gallery. https://christchurchartgallery.org.nz/media/uploads/2010_08/T heoSchoon.pdf (accessed 10 November 2016).

McAllister, March 2 2013, New Zealand Herald. www.nzherald.co.nz/janet-mcallister/news /archive.cfm?a_id=275 (accessed 10 November 2016).

MacLean, H. Walk re-creates Te Maiharoa's journey. 16 January 2016. Otago Daily Times. https://www.odt.co.nz/regions/northotago/walk-re-creates-te-maiharoa's-journey (accessed 10 November 2016).

Joseph, P. (2012). Tatarakihi - The Children of Parihaka, www.parihakafilm.com; https://www.nzonscreen.com).

Te Kanawa, W. Māori Students travel to Rarotonga to retrace the footsteps of their ancestors. Thurs 30 July 2015, Mãori Television. http://www.maoritelevision.com/news/national/maori-studentstravel-rarotonga-retrace-footsteps-their-ancestors (accessed 10 November 2016).

Te Karere, $\quad$ April $\quad 4 \quad 2016$. https://www.youtube.com/watch?v=tWmkQfvdLOc

Judge, B. 2012. Youtube: Te Heke 2012 Waitaki Mouth to Omarama. https://www.youtube.com/watch?v=ZdfUMooFPow (accessed 10 November 2016).

Descendants retrace Rua Kenana's footsteps up Maungapōhatu. Te Karere. January 01 2014: tvnz.co.nz/te-karere.../descendantsretrace-rua-kenana-s-footsteps-up-maungap-hatu

Descendants retrace Rua Kenana's footsteps up Maungapōhatu. Te Karere TVNZ. December 31 2013: https://www.youtube.com/watch?v=VvVASWSLo_k (accessed 10 November 2016).

\section{Newspapers}

NZ Herald. Janet McAllister: Art before art history began. March 2 2013. (accessed 20 September 2016). nzherald.co.nz.

Papers Past. The Premier and the Natives of Waitake South. Evening 
Star.

1886-01-07,

p.4.

https://paperspast.natlib.govt.nz/newspapers/evening-

star/1886/1/7/4 (accessed 10 November 2016).

Papers Past. The Premiere and the Natives at Waitaki South. Otago

Witness. 1886-01-09, p.18.

https:// paperspast.natlib.govt.nz/newspapers/otago-

witness/1886/1/9 (accessed 10 November 2016).

\section{Figures}

Figure 1: 'The Promised Land' at Omarama, on the lake side of Prohibition road. Here Te Maihāroa and his people established a Māori village 1877-1879. Personal whānau collection.

Figure 2: Te Heke (The Migration) to Omarama 1878. Source: Hocken Library, Asset ID 22772.

Figure 3: Te Poho o Te Rakitamau or locally known as Māori Hummock.

The area where Te Maihāroa's wife, Kahuti is buried (Mikaere, 1988: 68 \& 141; Te Maihāroa, 1957: 38; Beattie, E-21: 12).

Figure 4: Two of the ceremonial pieces made especially for this event. 27th December 2012. Personal whānau collection.

Figure 5: Lighting a fire the traditional way by rubbing two sticks together and one of the fire-keepers maintaining the fire embers the next morning. Waitaki River mouth. 26 \& 27 December 2012. Personal whānau collection.

Figure 6: The 'hue tapu' the vessel that carried the sacred water from the mouth of the Waitaki River to the Ahuriri River. Omarama. 30th December 2012. Personal whānau collection.

Figure 7: Two generations of fire carriers. The fire embers are maintained within the fungi, carried in a openly woven bag to let the air circulate and the remaining evidence of the fire embers that had been smouldering within the net bag. 28 December 2012 . Duntroon. Personal whānau collection.

Figure 8: Some of the fire and water carriers in front of some of the protected rock art at Takiroa. 28 $8^{\text {th }}$ December 2012. Duntroon. Personal whānau collection.

Figure 9: The popular 'yellow tardis', with whānau in a queue to visit the mobile port-a-1oo. 28 $8^{\text {th }}$ December 2012. Otematata. Personal whānau collection.

Figure 10: Carrying the sacred waters from the Waitaki River mouth back to the Ahuriru River, during a heke to remember their ancestor Te Maiharoa. 28 ${ }^{\text {th }}$ December 2012. Otago Daily Times, 2 January 2013. Photo by Andrew Ashton.

Figure 11: A 'tohu' interpreted as a sign by the whānau that our tīpuna were happy with our accomplishments. 30 ${ }^{\text {th }}$ December 2012. Otematata. Personal whānau collection.

Figure 12: Whānau enjoying a picnic together, after morning of rain. 30th December 2012. Otematata. Personal whānau collection.

Figure 13: These two photographs capture whānau at the top and bottom of the pass near Prohibition Road, Omarama. 30 December 
2012. Personal whānau collection.

Figure 14: Closing ceremony, where the water carried from the mouth of the Waitaki River was returned to the Ahuriri Stream. Omarama. 30th December 2012. Personal whānau collection.

Figure 15: Upoko Rangimārie Te Maihāroa and Tiamana Anne Te Maihāroa Dodds after the closing ceremony. Rangi passed away in 2015. Omarama. 30th December 2012. Personal whānau collection. 